\title{
An Investigation of the Current Autonomy Status of the Malaysian Public and Private Universities: An Empirical Result
}

\section{Basheer Al-haimi, Daing Nasir Ibrahim, and Ab Hamid MR}

Faculty of Industrial Management, Universiti Malaysia Pahang, Lebuhraya Tun Razak, 26300 Gambang, Pahang, Malaysia

\section{Abstract}

The benefits and importance of university autonomy for facilitating and accelerating higher education transformation have been broadly agreed by many higher education stakeholders. This paper aims to investigate the Malaysian public and private universities degree of independence and autonomy from the government and other external forces. The extent of an institute's autonomy is measured based on their independent in appointive, academic, administrative, and financial matters. An emailed survey has been sent to top-level management of 28 public and private universities

Corresponding Author: Basheer Al-haimi basheerump@gmail.com

Received: 5 August 2019 Accepted: 14 August 2019 Published: 18 August 2019

Publishing services provided by Knowledge E

(c) Basheer Al-haimi et al. This article is distributed under the terms of the Creative Commons Attribution License, which permits unrestricted use and redistribution provided that the original author and source are credited.

Selection and Peer-review under the responsibility of the FGIC2019 Conference Committee.

\section{G OPEN ACCESS} in Malaysia, resulting in 126 respondents. The respondents for the survey consisted of vice-chancellors, deputy vice-chancellors, deans, directors, and deputy deans. Using SPSS statistical software, data were analyzed by descriptive and inferential statistical analysis. The results demonstrate that the majority of the components under academic matters, administrative and financial matters are considered high autonomy, with less interference of the government over those institutions. With some reason, autonomy related to the appointment of the vice-chancellors and dismissals of rectors and vice-chancellors is still under government control. However, based on the findings, autonomy development at public and private universities in Malaysia has been engaged in a long journey that enabled it to compete and to progress well at the global level.

Keywords: universities, autonomy, Malaysia

\section{Introduction}

Higher Education is considered to be the cornerstone of any country's development, growth, and prosperity of its people. The contribution made by Higher Education Institutes (HEIs), play a significant role in the cultural and intellectual growth of a nation on a macro and micro scale. Higher education institutions contribute to the technology, economy, social, and cultural advancement of the country (Milton \& Barakat, 2016). For this reason, over the last few decades, Higher Education has become of the essential institutes that grow a country on several levels (Kimenyi, 2011). Thus, many countries, 
including Malaysia, have strengthened their education systems in order to cope with the new changes and challenges of the world.

Generally, higher education systems have gone through dramatic changes with the increase in many aspects such as internationalization, research and innovation, students bodies and the growing number of students enrolled in tertiary education has led to the need for universities to become more self-governing and autonomous (Henard \& Mitterle, 2009). Self-governance and full academic freedom in universities play a significant role in managing universities efficiently and adequately. (Salmi, 2009) linked the success of universities and the way of getting World Class University (WCU) status to three complementary sets of factors: concentration of talent, self-governance and full autonomy and abundant resources. Hence, many prestigious universities in the world have full autonomous status. However, universities in developing countries are not self-governed and are controlled by their government systems (Lee, 2013). In addition, a World Bank study entitled "The Road to Academic Excellence: The making of world-class research universities", found that new universities that are equipped with academic talent, financial resources and governance, particularly autonomy and academic freedom, can grow into top-quality research institutions within two or three decades (Sharma, 2011). Thus, academic freedom and university autonomy are essential factors for strengthening HEls and achieving WCU status.

Higher Education in Malaysia has also gone through many development transformations and reforms (Sirat, 2013). In order to cope with the new changes, challenges and competition of the world, the Malaysian government, spent a great deal of effort into strengthening the higher education system as a response to these changes and challenges. These efforts allowed Malaysia to enter into the global competition and become one of the international hubs for students from all over the world. These efforts are present in the strategic plans that aimed to ensure that the HEls are encouraged to achieve excellence and be able to compete on an international scale (Education, 2007). For instance, the Malaysian Education Blueprint (MEB) 2015-2025 laid out 10 shifts to catalyze continued excellence in Malaysia's higher education. One of these 10 shifts is empowering governance.

Thus, recognizing the importance of autonomy in facilitating and accelerating the transformation of Malaysian higher education institutions, the Malaysian government has given the autonomy status to many public universities, particularly to the institutes that focus primarily on research. Although the government had granted the public universities full autonomy, it is still argued that some universities are not yet fully autonomous institutions (SUFEAN HUSSIN, 2019). Similarly, (Wan, 2017) stated that "the 
autonomous status awarded to certain public universities only represents a fraction of the autonomy that public universities used to have." Since Malaysia is aspiring to have more world-class universities and in-line with a strong higher education system, this study was carried out to empirically investigate to what extent are Malaysian universities autonomous, as well as the different types of autonomy models that are granted to these universities. Moreover, to the best of our knowledge, few empirical studies have been carried out to cover all the dimensions related to autonomy, wherein previous studies focused on some of the academic and administrative matters, this study will cover appointive, academic, administrative and financial matters.

This paper is organized into five sections. The first section provides a basic introduction, as well as elaborating on the problem background. The second section focuses on the literature review related to autonomy both on a general and Malaysian perspectives. The third section elaborates on the methodology used in this research. The fourth section is the data analysis section, which is followed by a fifth section, which is the findings and discussion of the research, which discusses the results and the implications of those aforementioned results.

\section{Literature Review}

Autonomy in HEl has increasingly become an important factor that is essential for improving a university's performance and success (Al-haimi, Ab Hamid, \& Hujainah, 2018). However, autonomy is defined in several different contexts, some of which is unique to the HEls. Thus, there needs to be an understanding of the word first and what it would mean in the context of HEls. There are many definitions for university autonomy described by many agencies and scholars. According to the Lima Declaration on Academic Freedom and Autonomy of Institutions of Higher Education (1988), University Autonomy is defined as "the independence from the state and other pressures of society to make decision regarding its self-government, finance, administration and to establish its policies of education, research, extension work and other related activities"(WUS, 1988). European Universities Association outlines it as including organizational, financial, staffing and academic independence of Universities (Estermann, Nokkala, \& Steinel, 2011).

For a better understanding of the meaning of university autonomy, Gornitzka and Maaen categorized university autonomy into four types 1 ) the fully non-autonomous centerline state control, 2) the traditional academic autonomy, 3 ) the semi-autonomous corporate state and 4) the fully autonomous corporate model. Thus, university autonomy 
can be defined as the degree to which a university's academic and managerial entities enjoy the freedom to make decisions with less interference and control by the state. (Levy, 1980) published a study that aimed at shedding light on the defining variables in university autonomy and its relationship between the government and the university as two intertwined entities. The study was conducted in Mexico, with the relationship being analyzed through the lens of the involved universities and the Mexican government. In this study, autonomy is defined as the degree of authority the university practices and how much control it has over its various sub-entities and the outcome of the decisions that are made. Furthermore, Levy stated that "the extent of autonomy can be classified into three components of self-government, namely, appointive, academic, and financial" (Levy, 1980). Table 1 shows the components of self-governance in university autonomy.

TABLE 1: Components of Self-government for University Autonomy (Source: Levy (1980)).

\begin{tabular}{ll}
\hline Nature of Relations & Degree of Autonomy \\
\hline Appointive & - hiring, promotion, and dismissal of professors \\
& - selection and dismissal of deans, rectors, and other administrative personnel \\
& - terms of employment \\
Academic & - Access admission to the university \\
& - career selection \\
& - curriculum offerings and course instruction \\
& - degree requirements and authorization \\
& - academic freedom \\
& - determination of who pays \\
Financial & - funding level \\
& - funding criteria \\
& - preparation and allocation of university budget \\
& - accountability \\
\hline
\end{tabular}

The aforementioned definitions of autonomy directed us to the importance of university autonomy and highlighted the reason behind the rise and popularity of this topic among many researchers and academics. In the current century, flexibility and agility are a must, as the world is being geared more towards external factors such as globalization and global competitiveness. (Sadlak \& Liu, 2007) stated that: "institutions that have complete autonomy are also more flexible because they are not restricted by heavy bureaucracies and externally imposed standards, in spite of the legal accountability mechanisms that observe them." As a result, they can manage their resources with agility and quickly respond to the demands of a rapidly changing global market".

Moreover, experts have linked a HEls performance to autonomy or good governance of the university. These factors are also contributing criteria in achieving the WCU status. Jamil Salmi, the higher education expert related to the achievement of world-class university status to three complementary sets of factors with autonomy and academic freedoms as one of the quintessential elements (Salmi, 2009). An empirical study at Europe and the United States universities examined the relationship between the 
university autonomy and their performance and productivity and the findings indicated a strong correlation between these indices and the university output (Aghion, Dewatripont, Hoxby, Mas-Colell, \& Sapir, 2010).

Furthermore, a study conducted in the form of a survey discovered that the postsecondary education system in the US was considered to be the "the best in the world," due to universities being wealthy, independent of state control, fiercely competitive, and innovative. It was observed that this environment created educational institutions that promoted competitiveness, unrestrained scientific inquiry, critical thinking, innovation, and creativity. This contrasts with German and French universities that have excellent educational systems, but each nation has few world-class universities, with the best university in France and Germany in 2006 being ranked by SJTU 46th and 51st, respectively (Salmi, 2009). This is due to a lack of student screening and a noncompetitive environment. Both Germany and France also have educational systems that lack autonomy, with universities being constrained by rigid management control and civil-service employment rules, preventing them from offering the salaries necessary to attract world-class talent. France also has a two-tiered post-secondary education system, with the best scoring students being admitted into engineering and professional schools, leaving other universities to admit the bulk of students (Salmi, 2009).

The number of students in public and private institutions has expanded significantly, which consequently has made the higher education system as a whole, a more complex entity. Thus, such an unsustainable model has led many countries to look for other alternatives such as supervising model rather than a control model (Fielden, 2008). Table 2 shows the example of universities autonomy practices in selected countries. For instance, Malaysian university autonomy extends to only 4 categories, namely academic tenure, selection of textbooks, research priorities, and approval of publication. The results seem to be in contrast to what is currently practiced at Malaysian universities. Therefore, due to the importance of the governance at the universities level, the level of freedom of the universities to manage their affairs as well as the lack of knowledge to what extent Malaysian universities are free to govern their internal governance aspects, this research attempts to fill this gap. This can be done by examining the two type of institutional autonomy, which is related to academic and research matters and procedural autonomy that is related to non-academic matters (Bladh, 2007). 
TABLE 2: University Autonomy in Selected Countries.

\begin{tabular}{|c|c|c|c|c|c|c|}
\hline Category & HOL & UK & DEN & CAN & MAS & PAK \\
\hline Appointment / dismissal of VCs & $\bar{X}$ & $\mathrm{X}$ & $\bar{X}$ & $\mathrm{X}$ & & $\bar{X}$ \\
\hline Appointment/dismissal of Professors & $\mathrm{X}$ & $\mathrm{X}$ & $\mathrm{X}$ & $\mathrm{X}$ & & $\mathrm{X}$ \\
\hline Academic tenure & $\mathrm{X}$ & $\mathrm{X}$ & $\mathrm{X}$ & $\mathrm{X}$ & $\mathrm{X}$ & $\mathrm{X}$ \\
\hline Academic pay and conditions & & & & $\mathrm{X}$ & & $\mathrm{X}$ \\
\hline Students entry standards & & $\mathrm{X}$ & & $\mathrm{X}$ & & $\mathrm{X}$ \\
\hline Selection of students & & $\mathrm{X}$ & & $\mathrm{X}$ & & $\mathrm{X}$ \\
\hline Size of enrollments & $\mathrm{X}$ & $\mathrm{X}$ & $\mathrm{X}$ & $\mathrm{X}$ & & $\mathrm{X}$ \\
\hline Quotas for special groups & $\mathrm{X}$ & $\mathrm{X}$ & $\mathrm{X}$ & $\mathrm{X}$ & & \\
\hline Language of instruction & & $\mathrm{X}$ & & $\mathrm{X}$ & & $\mathrm{x}$ \\
\hline $\begin{array}{l}\text { Introduction of new courses/elimination of old } \\
\text { courses }\end{array}$ & $\mathrm{X}$ & $\mathrm{X}$ & & $\mathrm{X}$ & & $\mathrm{X}$ \\
\hline Selection of textbooks & $\mathrm{x}$ & $\mathrm{X}$ & $\mathrm{x}$ & $\mathrm{X}$ & $\mathrm{X}$ & $\mathrm{X}$ \\
\hline Examination/graduation standards & $\mathrm{X}$ & $\mathrm{X}$ & & $\mathrm{X}$ & & $\mathrm{X}$ \\
\hline Decision to teach courses at graduate level & $\mathrm{X}$ & $\mathrm{X}$ & & $\mathrm{X}$ & & $\mathrm{X}$ \\
\hline Research priorities & $\mathrm{X}$ & $\mathrm{X}$ & $\mathrm{X}$ & $\mathrm{X}$ & $\mathrm{X}$ & $\mathrm{X}$ \\
\hline Approval of publications & $\mathrm{X}$ & $\mathrm{X}$ & $\mathrm{X}$ & $\mathrm{X}$ & $\mathrm{X}$ & $\mathrm{X}$ \\
\hline $\begin{array}{l}\text { Membership and control of governing } \\
\text { council/board }\end{array}$ & & $\mathrm{X}$ & $\mathrm{X}$ & $\mathrm{X}$ & & $\mathrm{X}$ \\
\hline Management of university budget & $\mathrm{X}$ & $\mathrm{X}$ & & $\mathrm{X}$ & & $\mathrm{X}$ \\
\hline Level of tuition fees & & $\mathrm{X}$ & & & & \\
\hline Approval of income generation ventures & $\mathrm{X}$ & $\mathrm{X}$ & & $\mathrm{X}$ & & $\mathrm{X}$ \\
\hline Own buildings and equipment & $\mathrm{X}$ & $\mathrm{X}$ & & $\mathrm{X}$ & & $\mathrm{X}$ \\
\hline Ability to borrow funds & $\mathrm{X}$ & $\mathrm{X}$ & $\mathrm{X}$ & $\mathrm{X}$ & & $\mathrm{X}$ \\
\hline
\end{tabular}

Note: $\mathrm{X}$ means the university is independent to take a decision; HOL is Holland, the UK is the United Kingdom, DEN is Denmark, CAN is Canada, MAS is Malaysia and PAK is Pakistan. Source: Fielden (Fielden).

\section{Methodology}

To understand the perceptions of the respondents on the autonomy practices at their respective Malaysian public and private institutions, this research employed quantitative research method. This study proceeded by questionnaire using an email survey sent to vice-chancellors, deputy vice-chancellors, directors, deans and deputy deans of 28 public and private universities. Table 3 shows the demographics of the participated respondents.

\section{Results and Discussion}

This study was carried out to empirically investigate in-depth all the dimensions of autonomy at the Malaysian public and private universities. These dimensions are related to an appointment (see Table 4), academic matters (see Table 5) and administrative and financial matters (see Table 6). The respondents were asked to rank the degree of autonomy and the influence of the government and other agencies at their respective universities. The instrument and scale used for this study ranged from $1=$ extremely low to $7=$ extremely high. 
TABLE 3: Demographics of Respondents.

\begin{tabular}{|c|c|c|}
\hline Item & Frequency & Percentage (\%) \\
\hline \multicolumn{3}{|l|}{ Title } \\
\hline Professor & 53 & 42.1 \\
\hline Associate Professor & 47 & 37.3 \\
\hline $\mathrm{Dr}$ & 25 & 19.8 \\
\hline $\mathrm{Mr}$ & 1 & .8 \\
\hline \multicolumn{3}{|l|}{ Gender } \\
\hline Male & 84 & 66.7 \\
\hline Female & 42 & 33.3 \\
\hline \multicolumn{3}{|l|}{ Job } \\
\hline Ministry Higher Education Top Management & 1 & .8 \\
\hline Vice Chancellor & 2 & 1.6 \\
\hline Deputy Vice Chancellor & 7 & 5.6 \\
\hline Associate Vice Chancellor & 2 & 1.6 \\
\hline Faculty Dean & 30 & 23.8 \\
\hline Deputy Dean & 71 & 56.3 \\
\hline Director & 13 & 10.3 \\
\hline \multicolumn{3}{|l|}{ Experience (Years) } \\
\hline $1-2$ & 2 & 1.6 \\
\hline $3-5$ & 5 & 4.0 \\
\hline $6-10$ & 9 & 7.1 \\
\hline $11-15$ & 26 & 20.6 \\
\hline Above 15 & 84 & 66.7 \\
\hline \multicolumn{3}{|l|}{ University Age } \\
\hline \multicolumn{3}{|l|}{ University Type } \\
\hline Public & 113 & $89.7 \%$ \\
\hline Private & 13 & $10.3 \%$ \\
\hline \multicolumn{3}{|l|}{ University Category } \\
\hline Research University & 55 & $43.3 \%$ \\
\hline Comprehensive University & 20 & $15.7 \%$ \\
\hline Focused University & 51 & $40.2 \%$ \\
\hline
\end{tabular}

As shown in Table 4, public universities show more interference and influenced by the government in terms of appointment of VCs / Rectors, dismissal of CEO/rectors, academic pay and conditions followed by appointment of professors representing mean values as 6.21, 5.78, 4.57 and 3.17 respectively (see at mean column). Furthermore, an independent sample test (t-test) has been conducted to statistically explain the difference between these scores and whether the scores are statistically significant. However, an independent t-test result found the aforementioned components to be significant, whereby $p$-value $<0.05$ (see appendix A). Thus, both tests revealed that the 
TABLE 4: The Overall Mean Score of Respondents Related to Autonomy (Appointment).

\begin{tabular}{lcccc}
\hline Dimension 1 & \multicolumn{3}{c}{$\begin{array}{c}\text { Appointive: In light of university autonomy, to what extent } \\
\text { does the Government directly influence the following items? }\end{array}$} \\
\hline University type & \multicolumn{2}{c}{ Public Universities } & \multicolumn{2}{c}{ Private Universities } \\
Items & Mean & Std.Dev. & Mean & Std.Dev. \\
Appointment of CEO (VC/Rector) & 6.21 & 1.16 & 2.54 & 1.33 \\
Dismissal of Chief Executive Officers & 5.78 & 1.48 & 2.54 & 1.39 \\
Appointment of Professors. & 3.17 & 1.74 & 2.15 & 1.34 \\
Dismissal of professors & 2.80 & 1.61 & 2.54 & 1.50 \\
Appointment of other academic staff & 2.73 & 1.66 & 2.54 & 1.50 \\
Termination or discipline of academic staff. & 2.81 & 1.64 & 2.08 & .76 \\
Academic tenure & 2.80 & 1.71 & 1.85 & .55 \\
Appointment or dismissal of general staff & 2.50 & 1.44 & 2.00 & 1.08 \\
Academic pay and conditions & 4.57 & 1.78 & 2.69 & 1.43 \\
\hline
\end{tabular}

government has more control over the appointment of VCs, dismissal of CEO/rectors, academic pay and conditions, and less interference on the other components. The reason behind this might be due to the over-dependence on public funds whereby $70 \%$ to $80 \%$ of the budget spent on public HEls are from the government (Hock-Eam, Taib, Abdullah, Adiana, \& Hwa, 2016). Hence, the government oversees and monitors the spending of those funds, and treats the HEls like any other government agency. This forces the universities into a specific strategic plan set by the government.

Likewise, in private universities, the influence and interference of the government are considered very low compared to public universities. However, there is an exception for academic pay and conditions, which shows high results in the mean's score as 2.69 , which is considered to be low when compared to public universities. On the other hand, public and private universities show more independence in terms of appointment of general and academic staff and academic tenure. The results indicate that private universities are comparatively more autonomous in terms of appointment while the development of autonomy at public universities is ongoing which is considered to be acceptable and healthy for the higher education system in Malaysia as a whole. The second dimension for this study covered the academic matters related to students, curriculum and teaching, academic standards, research and publication, and governance. In this dimension, the respondents were asked to rate the degree level of independence and authority of their universities to take decisions related to the aforementioned academic matters. Interestingly, the results show that public and private universities both have high autonomy and more authority to make decisions on all the academic matters, as displayed in Table 5. Also, the t-test result shown in appendix 2 indicates that there are no differences between public and private universities in most of academic matters components. A few academic matters such as entry standards, methods for selection students, the quota for minority group and accreditation of institutions and courses are among the academic matters in which the government moderately controls 
TABLE 5: The Overall Mean Score of Respondents Related to Academic Matters.

\begin{tabular}{|c|c|c|c|c|c|}
\hline \multicolumn{2}{|c|}{ Dimension2 } & \multicolumn{4}{|c|}{$\begin{array}{l}\text { Academic : The extent to which your university is } \\
\text { independent and has the authority to make decisions } \\
\text { with regards to the following academic matters: }\end{array}$} \\
\hline \multirow{6}{*}{ 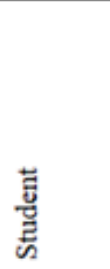 } & \multirow[b]{2}{*}{ Entry standards } & \multicolumn{2}{|c|}{ Public Universities } & \multicolumn{2}{|c|}{ Private Universities } \\
\hline & & $\begin{array}{c}\text { Mean } \\
5.26\end{array}$ & $\begin{array}{l}\text { Std.Dev. } \\
1.20\end{array}$ & $\begin{array}{c}\text { Mean } \\
4.23\end{array}$ & $\begin{array}{l}\text { Std.Dev. } \\
1.481\end{array}$ \\
\hline & $\begin{array}{l}\text { Methods for selection and admission of } \\
\text { students }\end{array}$ & 5.05 & 1.26 & 4.31 & 1.316 \\
\hline & Quotas for minority group & 4.85 & 1.46 & 4.77 & 1.166 \\
\hline & Pass and failure rate & 5.21 & 1.56 & 5.15 & 987 \\
\hline & Discipline of students & 5.23 & 1.50 & 5.54 & .776 \\
\hline \multirow{6}{*}{ 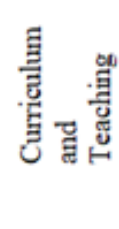 } & Methods of teaching & 5.52 & 1.50 & 5.15 & .801 \\
\hline & Methods of examination & 5.57 & 1.487 & 5.23 & 927 \\
\hline & Language of instruction & 5.49 & 1.513 & 5.54 & .776 \\
\hline & Introduction of new teaching fields. & 5.30 & 1.413 & 5.38 & .768 \\
\hline & Termination of teaching fields. & 5.14 & 1.322 & 5.31 & .855 \\
\hline & Entry standards of students & 5.56 & 1.110 & 4.85 & 1.214 \\
\hline \multirow{5}{*}{ 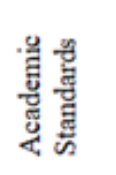 } & Graduation standards & 5.81 & 1.00 & 5.31 & .85 \\
\hline & Standards in particular subjects & 5.75 & 1.13 & 5.38 & 1.04 \\
\hline & Quality Audits & 5.57 & 1.18 & 5.31 & .75 \\
\hline & Accreditation of institutions & 5.58 & 1.28 & 4.54 & 1.45 \\
\hline & Accreditation of courses & 5.38 & 1.37 & 4.62 & 1.26 \\
\hline \multirow{5}{*}{ 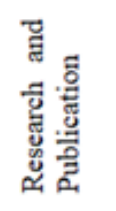 } & To open postgraduate studies. & 5.52 & 1.166 & 5.15 & 1.14 \\
\hline & Research Priorities. & 5.55 & 1.427 & 6.00 & .91 \\
\hline & Particular research topics. & 5.59 & 1.237 & 5.54 & .77 \\
\hline & Approval of publications. & 5.35 & 1.433 & 5.54 & 1.45 \\
\hline & $\begin{array}{l}\text { Restriction on public statements by academic } \\
\text { staff. }\end{array}$ & 4.84 & 1.411 & 5.46 & .77 \\
\hline \multirow{5}{*}{ 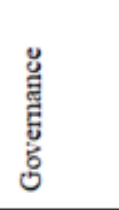 } & $\begin{array}{l}\text { Membership of governing councils of } \\
\text { institutions. }\end{array}$ & 5.06 & 1.403 & 5.85 & .89 \\
\hline & Control of governing council. & 5.01 & 1.271 & 5.85 & .89 \\
\hline & Membership of academic boards. & 5.44 & 1.239 & 5.92 & .86 \\
\hline & Control of academic boards. & 5.38 & 1.270 & 5.92 & .86 \\
\hline & Control of student association. & 5.35 & 1.374 & 5.15 & 1.281 \\
\hline
\end{tabular}

(particularly in private universities) whereby the mean scores and t-test indicate such differences. As a result, the effort of the government towards granting HEls the full autonomy status will lead to better a performance in Higher Education, and it would allow the institutes to compete on a global scale.

Furthermore, Table 6 displays the results related to administrative and finance matters at public and private institutions of Malaysia. From the results shown above, it can be observed that public and private universities are relatively equal in controlling the components that relate to administrative and financial matters. The mean scores for all components are greater than 5 , with the exception of the level of tuition fees at the public universities, which is 4.71 . This result indicates less interference and influence from the government over the public and private universities in Malaysia. In line with this result, the t-test performed in this study revealed no differences between public and private universities in all the components related to administrative and financial matters whereby the $p$-value is greater than 0.05 except with the level of tuition fees (see appendix 3). However, this result is consistent with what has been declared by the 
Malaysian government from time to time, which is that they have granted the autonomy status to all public universities.

TABLE 6: The Overall Mean Score of Respondents Related to Administrative and Finance.

Dimension 3
University type
Items
Student numbers.
Student numbers in particular fields.
Closure or amalgamation of institutions
University rules and regulation.
Duration of academic year.
Financial audit
Preparation and allocation of university
budget.
Approval of commercial or money making
projects.
Approval of major capital expenditure.
Level of tuition fees.
Financial support to students.
Accountability.

\begin{tabular}{|c|c|c|c|}
\hline \multicolumn{2}{|c|}{ Public Universities } & \multicolumn{2}{|c|}{ Private Universities } \\
\hline Mean & Std.Dev. & Mean & Std.Dev. \\
\hline 5.31 & 1.203 & 5.15 & 1.214 \\
\hline 5.19 & 1.194 & 5.08 & 1.038 \\
\hline 5.04 & 1.319 & 5.08 & .641 \\
\hline 5.37 & 1.219 & 5.46 & .967 \\
\hline 5.27 & 1.296 & 4.85 & 1.519 \\
\hline 5.27 & 1.239 & 5.54 & .776 \\
\hline 5.27 & 1.382 & 5.62 & .768 \\
\hline 5.27 & 1.311 & 5.31 & .751 \\
\hline 5.25 & 1.386 & 5.46 & .967 \\
\hline 4.71 & 1.551 & 5.38 & .870 \\
\hline 5.08 & 1.565 & 5.31 & .855 \\
\hline 5.60 & 1.161 & 5.77 & .832 \\
\hline
\end{tabular}

\section{Conclusion}

Higher Education Institutes are always under pressure to grow and improve their performance, as the world is becoming more global, which requires them to be highly agile and adaptive to change as well as having a high degree of responsiveness. In order to achieve this goal effectively and efficiently, self-governance and autonomy of universities are an essential factor. Many successful universities around the world are granted the full autonomy status by their governments that have geared them towards excellence.

Malaysia is a developing nation that strives for a high performing economy and education system. By giving a full autonomy status to its universities, it has contributed to growth and degree of excellence in which has made Malaysia globally competitive. This study revealed a rapid and effective autonomy development at Malaysian public and private universities in terms of academic and administrative and financial matters. However, at public universities, a few components related to the appointment of vicechancellors, deputy vice-chancellors, and academic pay and conditions are still in 
control of the government. This could be improved by relying less on public funds where the government might have the right to regulate and oversee how these budgets are spent and keep track of their performance and holds them accountable.

\section{Appendices}

\section{Appendix 1}

\section{Independent Sample t-test (Appointment)}

\begin{tabular}{|c|c|c|c|c|c|c|}
\hline & & \multicolumn{2}{|c|}{$\begin{array}{l}\text { Levene's } T \text { Te } \\
\text { for Equality } \\
\text { Variances }\end{array}$} & t-test for & \multicolumn{2}{|c|}{ quality of Means } \\
\hline & & $\mathrm{F}$ & Sig. & $\mathrm{t}$ & df & $\begin{array}{c}\text { Sig. } \\
\text { (2-tailed) }\end{array}$ \\
\hline \multirow[t]{2}{*}{$\begin{array}{l}\text { Appointment of } \\
\text { VC/Presidents/Rectors }\end{array}$} & $\begin{array}{l}\text { Equal variances } \\
\text { assumed }\end{array}$ & 1.184 & .279 & 10.647 & 124 & .000 \\
\hline & $\begin{array}{l}\text { Equal variances not } \\
\text { assumed }\end{array}$ & & & 9.549 & 14.183 & .000 \\
\hline \multirow[t]{2}{*}{ Dismissal CEO } & $\begin{array}{l}\text { Equal variances } \\
\text { assumed }\end{array}$ & .133 & .716 & 7.488 & 124 & .000 \\
\hline & $\begin{array}{l}\text { Equal variances not } \\
\text { assumed }\end{array}$ & & & 7.895 & 15.330 & .000 \\
\hline \multirow[t]{2}{*}{$\begin{array}{l}\text { Appointment of } \\
\text { Professors }\end{array}$} & $\begin{array}{l}\text { Equal variances } \\
\text { assumed }\end{array}$ & 5.756 & .018 & 2.028 & 124 & .045 \\
\hline & $\begin{array}{l}\text { Equal variances not } \\
\text { assumed }\end{array}$ & & & 2.490 & 17.014 & .023 \\
\hline \multirow[t]{2}{*}{ Dismissal of Professors } & $\begin{array}{l}\text { Equal variances } \\
\text { assumed }\end{array}$ & 1.191 & .277 & .550 & 124 & .583 \\
\hline & $\begin{array}{l}\text { Equal variances not } \\
\text { assumed }\end{array}$ & & & .581 & 15.333 & .570 \\
\hline \multirow[t]{2}{*}{$\begin{array}{l}\text { Appointment of other } \\
\text { Academic Staff }\end{array}$} & $\begin{array}{l}\text { Equal variances } \\
\text { assumed }\end{array}$ & 1.246 & .267 & .388 & 124 & .698 \\
\hline & $\begin{array}{l}\text { Equal variances not } \\
\text { assumed }\end{array}$ & & & .420 & 15.553 & .680 \\
\hline \multirow[t]{2}{*}{$\begin{array}{l}\text { Termination or discipline } \\
\text { of Academic Staff }\end{array}$} & $\begin{array}{l}\text { Equal variances } \\
\text { assumed }\end{array}$ & 14.891 & .000 & 1.576 & 124 & .117 \\
\hline & $\begin{array}{l}\text { Equal variances not } \\
\text { assumed }\end{array}$ & & & 2.789 & 27.505 & .009 \\
\hline \multirow[t]{2}{*}{ Academic tenure } & $\begin{array}{l}\text { Equal variances } \\
\text { assumed }\end{array}$ & 21.625 & .000 & 1.983 & 124 & .050 \\
\hline & $\begin{array}{l}\text { Equal variances not } \\
\text { assumed }\end{array}$ & & & 4.267 & 46.709 & .000 \\
\hline $\begin{array}{l}\text { Appointment or } \\
\text { dismissal general staff }\end{array}$ & $\begin{array}{l}\text { Equal variances } \\
\text { assumed }\end{array}$ & 8.524 & .004 & 1.201 & 124 & .232 \\
\hline
\end{tabular}




\begin{tabular}{|c|c|c|c|c|c|c|}
\hline & & \multicolumn{2}{|c|}{$\begin{array}{l}\text { Levene's Te } \\
\text { for Equality } \\
\text { Variances }\end{array}$} & \multicolumn{3}{|c|}{ t-test for Equality of Means } \\
\hline & & $\mathrm{F}$ & Sig. & $\mathrm{t}$ & df & $\begin{array}{c}\text { Sig. } \\
\text { (2-tailed) }\end{array}$ \\
\hline & $\begin{array}{l}\text { Equal variances not } \\
\text { assumed }\end{array}$ & & & 1.507 & 17.332 & .150 \\
\hline \multirow[t]{2}{*}{$\begin{array}{l}\text { Academic pay and } \\
\text { conditions }\end{array}$} & $\begin{array}{l}\text { Equal variances } \\
\text { assumed }\end{array}$ & 1.021 & .314 & 3.643 & 124 & .000 \\
\hline & $\begin{array}{l}\text { Equal variances not } \\
\text { assumed }\end{array}$ & & & 4.333 & 16.597 & .000 \\
\hline
\end{tabular}

\section{Appendix 2}

\section{Independent Sample t-test (Academic Matters)}

\begin{tabular}{|c|c|c|c|c|c|c|}
\hline & & \multicolumn{2}{|c|}{$\begin{array}{l}\text { Levene's } T \text { Te } \\
\text { for Equality } \\
\text { Variances }\end{array}$} & \multicolumn{3}{|c|}{$\begin{array}{l}\text { Test t-test for Equality of Means } \\
\text { of }\end{array}$} \\
\hline & & $\mathrm{F}$ & Sig. & $\mathrm{t}$ & df & $\begin{array}{c}\text { Sig. } \\
\text { (2-tailed) }\end{array}$ \\
\hline \multirow[t]{2}{*}{ Entry standards } & $\begin{array}{l}\text { Equal variances } \\
\text { assumed }\end{array}$ & 1.620 & .206 & 2.846 & 124 & .005 \\
\hline & $\begin{array}{l}\text { Equal variances not } \\
\text { assumed }\end{array}$ & & & 2.409 & 13.877 & .031 \\
\hline \multirow{2}{*}{$\begin{array}{l}\text { Methods for selection } \\
\text { and admission of } \\
\text { students }\end{array}$} & $\begin{array}{l}\text { Equal variances } \\
\text { assumed }\end{array}$ & .015 & .904 & 2.002 & 124 & .047 \\
\hline & $\begin{array}{l}\text { Equal variances not } \\
\text { assumed }\end{array}$ & & & 1.942 & 14.678 & .072 \\
\hline \multirow[t]{2}{*}{$\begin{array}{l}\text { Quotas for minority } \\
\text { group }\end{array}$} & $\begin{array}{l}\text { Equal variances } \\
\text { assumed }\end{array}$ & .306 & .581 & .191 & 124 & .849 \\
\hline & $\begin{array}{l}\text { Equal variances not } \\
\text { assumed }\end{array}$ & & & .229 & 16.699 & .822 \\
\hline \multirow[t]{2}{*}{ Pass and failure rate } & $\begin{array}{l}\text { Equal variances } \\
\text { assumed }\end{array}$ & 1.471 & .227 & .132 & 124 & .895 \\
\hline & $\begin{array}{l}\text { Equal variances not } \\
\text { assumed }\end{array}$ & & & .188 & 19.723 & .852 \\
\hline \multirow[t]{2}{*}{ Discipline of students } & $\begin{array}{l}\text { Equal variances } \\
\text { assumed }\end{array}$ & 3.891 & .051 & -.725 & 124 & .470 \\
\hline & $\begin{array}{l}\text { Equal variances not } \\
\text { assumed }\end{array}$ & & & -1.197 & 24.157 & .243 \\
\hline \multirow[t]{2}{*}{ Methods of teaching } & $\begin{array}{l}\text { Equal variances } \\
\text { assumed }\end{array}$ & 3.829 & .053 & .869 & 124 & .387 \\
\hline & $\begin{array}{l}\text { Equal variances not } \\
\text { assumed }\end{array}$ & & & 1.400 & 23.252 & .175 \\
\hline Methods of examination & $\begin{array}{l}\text { Equal variances } \\
\text { assumed }\end{array}$ & 1.243 & .267 & .794 & 124 & .429 \\
\hline
\end{tabular}




\begin{tabular}{|c|c|c|c|c|c|c|}
\hline & & \multicolumn{2}{|c|}{$\begin{array}{l}\text { Levene's } T \epsilon \\
\text { for Equality } \\
\text { Variances }\end{array}$} & \multicolumn{3}{|c|}{$\begin{array}{l}\text { Test t-test for Equality of Means } \\
\text { of }\end{array}$} \\
\hline & & $\mathrm{F}$ & Sig. & $\mathrm{t}$ & df & $\begin{array}{c}\text { Sig. } \\
\text { (2-tailed) }\end{array}$ \\
\hline & $\begin{array}{l}\text { Equal variances not } \\
\text { assumed }\end{array}$ & & & 1.147 & 19.976 & .265 \\
\hline \multirow[t]{2}{*}{ Language of instruction } & $\begin{array}{l}\text { Equal variances } \\
\text { assumed }\end{array}$ & 3.262 & .073 & -.121 & 124 & .904 \\
\hline & $\begin{array}{l}\text { Equal variances not } \\
\text { assumed }\end{array}$ & & & -.200 & 24.276 & .843 \\
\hline \multirow[t]{2}{*}{$\begin{array}{l}\text { Introduction of new } \\
\text { teaching fields }\end{array}$} & $\begin{array}{l}\text { Equal variances } \\
\text { assumed }\end{array}$ & 3.755 & .055 & -.210 & 124 & .834 \\
\hline & $\begin{array}{l}\text { Equal variances not } \\
\text { assumed }\end{array}$ & & & -.333 & 22.806 & .742 \\
\hline \multirow[t]{2}{*}{$\begin{array}{l}\text { Termination of teaching } \\
\text { fields }\end{array}$} & $\begin{array}{l}\text { Equal variances } \\
\text { assumed }\end{array}$ & 1.200 & .275 & -.442 & 124 & .660 \\
\hline & $\begin{array}{l}\text { Equal variances not } \\
\text { assumed }\end{array}$ & & & -.620 & 19.354 & .542 \\
\hline \multirow[t]{2}{*}{$\begin{array}{l}\text { Entry standards of } \\
\text { students }\end{array}$} & $\begin{array}{l}\text { Equal variances } \\
\text { assumed }\end{array}$ & .124 & .725 & 2.169 & 124 & .032 \\
\hline & $\begin{array}{l}\text { Equal variances not } \\
\text { assumed }\end{array}$ & & & 2.018 & 14.402 & .063 \\
\hline \multirow[t]{2}{*}{ Graduation Standards } & $\begin{array}{l}\text { Equal variances } \\
\text { assumed }\end{array}$ & .021 & .886 & 1.710 & 124 & .090 \\
\hline & $\begin{array}{l}\text { Equal variances not } \\
\text { assumed }\end{array}$ & & & 1.949 & 16.099 & .069 \\
\hline \multirow[t]{2}{*}{$\begin{array}{l}\text { Standards in particular } \\
\text { subjects }\end{array}$} & $\begin{array}{l}\text { Equal variances } \\
\text { assumed }\end{array}$ & .281 & .597 & 1.111 & 124 & .269 \\
\hline & $\begin{array}{l}\text { Equal variances not } \\
\text { assumed }\end{array}$ & & & 1.191 & 15.475 & .252 \\
\hline \multirow[t]{2}{*}{ Quality Audits } & $\begin{array}{l}\text { Equal variances } \\
\text { assumed }\end{array}$ & 1.249 & .266 & .767 & 124 & .445 \\
\hline & $\begin{array}{l}\text { Equal variances not } \\
\text { assumed }\end{array}$ & & & 1.095 & 19.710 & .287 \\
\hline \multirow[t]{2}{*}{$\begin{array}{l}\text { Accreditation of } \\
\text { institutions }\end{array}$} & $\begin{array}{l}\text { Equal variances } \\
\text { assumed }\end{array}$ & .790 & .376 & 2.739 & 124 & .007 \\
\hline & $\begin{array}{l}\text { Equal variances not } \\
\text { assumed }\end{array}$ & & & 2.490 & 14.260 & .026 \\
\hline \multirow[t]{2}{*}{ Accreditation of courses } & $\begin{array}{l}\text { Equal variances } \\
\text { assumed }\end{array}$ & .012 & .915 & 1.919 & 124 & .057 \\
\hline & $\begin{array}{l}\text { Equal variances not } \\
\text { assumed }\end{array}$ & & & 2.053 & 15.458 & .057 \\
\hline \multirow[t]{2}{*}{$\begin{array}{l}\text { To open Postgraduate } \\
\text { studies }\end{array}$} & $\begin{array}{l}\text { Equal variances } \\
\text { assumed }\end{array}$ & .010 & .920 & 1.081 & 124 & .282 \\
\hline & $\begin{array}{l}\text { Equal variances not } \\
\text { assumed }\end{array}$ & & & 1.097 & 15.018 & .290 \\
\hline Research Priorities & $\begin{array}{l}\text { Equal variances } \\
\text { assumed }\end{array}$ & 3.376 & .069 & -1.112 & 124 & .268 \\
\hline
\end{tabular}




\begin{tabular}{|c|c|c|c|c|c|c|}
\hline & & $\begin{array}{l}\text { Levene's } \\
\text { for Equality } \\
\text { Variances }\end{array}$ & \multicolumn{4}{|c|}{$\begin{array}{l}\text { Test t-test for Equality of Means } \\
\text { of }\end{array}$} \\
\hline & & $\mathrm{F}$ & Sig. & $\mathrm{t}$ & df & $\begin{array}{c}\text { Sig. } \\
\text { (2-tailed) }\end{array}$ \\
\hline & $\begin{array}{l}\text { Equal variances not } \\
\text { assumed }\end{array}$ & & & -1.575 & 19.527 & .131 \\
\hline \multirow[t]{2}{*}{$\begin{array}{l}\text { Particular research } \\
\text { topics }\end{array}$} & $\begin{array}{l}\text { Equal variances } \\
\text { assumed }\end{array}$ & 2.481 & .118 & .155 & 124 & .877 \\
\hline & $\begin{array}{l}\text { Equal variances not } \\
\text { assumed }\end{array}$ & & & .223 & 19.849 & .826 \\
\hline \multirow[t]{2}{*}{ Approval of publications } & $\begin{array}{l}\text { Equal variances } \\
\text { assumed }\end{array}$ & .000 & .986 & -.439 & 124 & .661 \\
\hline & $\begin{array}{l}\text { Equal variances not } \\
\text { assumed }\end{array}$ & & & -.435 & 14.826 & .670 \\
\hline \multirow{2}{*}{$\begin{array}{l}\text { Restriction on public } \\
\text { statements by academic } \\
\text { staff }\end{array}$} & $\begin{array}{l}\text { Equal variances } \\
\text { assumed }\end{array}$ & 4.504 & .036 & -1.555 & 124 & .122 \\
\hline & $\begin{array}{l}\text { Equal variances not } \\
\text { assumed }\end{array}$ & & & -2.454 & 22.516 & .022 \\
\hline \multirow{2}{*}{$\begin{array}{l}\text { Membership of } \\
\text { governing councils of } \\
\text { institutions }\end{array}$} & $\begin{array}{l}\text { Equal variances } \\
\text { assumed }\end{array}$ & 3.993 & .048 & -1.963 & 123 & .052 \\
\hline & $\begin{array}{l}\text { Equal variances not } \\
\text { assumed }\end{array}$ & & & -2.776 & 19.582 & .012 \\
\hline \multirow[t]{2}{*}{$\begin{array}{l}\text { Control of governing } \\
\text { council }\end{array}$} & $\begin{array}{l}\text { Equal variances } \\
\text { assumed }\end{array}$ & 1.847 & .177 & -2.305 & 124 & .023 \\
\hline & $\begin{array}{l}\text { Equal variances not } \\
\text { assumed }\end{array}$ & & & -3.029 & 18.057 & .007 \\
\hline \multirow[t]{2}{*}{$\begin{array}{l}\text { membership of } \\
\text { academic boards }\end{array}$} & $\begin{array}{l}\text { Equal variances } \\
\text { assumed }\end{array}$ & 6.742 & .011 & -1.359 & 124 & .177 \\
\hline & $\begin{array}{l}\text { Equal variances not } \\
\text { assumed }\end{array}$ & & & -1.806 & 18.264 & .087 \\
\hline \multirow[t]{2}{*}{$\begin{array}{l}\text { Control of academic } \\
\text { boards }\end{array}$} & $\begin{array}{l}\text { Equal variances } \\
\text { assumed }\end{array}$ & 6.826 & .010 & -1.498 & 124 & .137 \\
\hline & $\begin{array}{l}\text { Equal variances not } \\
\text { assumed }\end{array}$ & & & -2.029 & 18.612 & .057 \\
\hline \multirow[t]{2}{*}{$\begin{array}{l}\text { Control of student } \\
\text { association }\end{array}$} & $\begin{array}{l}\text { Equal variances } \\
\text { assumed }\end{array}$ & .692 & .407 & .478 & 124 & .633 \\
\hline & $\begin{array}{l}\text { Equal variances not } \\
\text { assumed }\end{array}$ & & & .506 & 15.359 & .620 \\
\hline
\end{tabular}

\section{Appendix 3}

Independent Sample t-test (Administrative and Finance) 


\begin{tabular}{|c|c|c|c|c|c|c|}
\hline & & \multicolumn{2}{|c|}{$\begin{array}{l}\text { Levene's } T \epsilon \\
\text { for Equality } \\
\text { Variances }\end{array}$} & \multicolumn{3}{|c|}{$\begin{array}{l}\text { Test t-test for Equality of Means } \\
\text { of }\end{array}$} \\
\hline & & $\mathrm{F}$ & Sig. & $\mathrm{t}$ & $d f$ & $\begin{array}{l}\text { Sig. (2- } \\
\text { tailed) }\end{array}$ \\
\hline \multirow[t]{2}{*}{ Student numbers } & $\begin{array}{l}\text { Equal variances } \\
\text { assumed }\end{array}$ & .002 & .962 & .442 & 124 & .659 \\
\hline & $\begin{array}{l}\text { Equal variances not } \\
\text { assumed }\end{array}$ & & & .439 & 14.844 & .667 \\
\hline \multirow[t]{2}{*}{$\begin{array}{l}\text { Student numbers in } \\
\text { particular fields }\end{array}$} & $\begin{array}{l}\text { Equal variances } \\
\text { assumed }\end{array}$ & .902 & .344 & .341 & 124 & .734 \\
\hline & $\begin{array}{l}\text { Equal variances not } \\
\text { assumed }\end{array}$ & & & .381 & 15.895 & .708 \\
\hline \multirow{2}{*}{$\begin{array}{l}\text { Closure or } \\
\text { amalgamation of } \\
\text { institution }\end{array}$} & $\begin{array}{l}\text { Equal variances } \\
\text { assumed }\end{array}$ & 5.431 & .021 & -.088 & 124 & .930 \\
\hline & $\begin{array}{l}\text { Equal variances not } \\
\text { assumed }\end{array}$ & & & -.151 & 25.898 & .881 \\
\hline \multirow[t]{2}{*}{$\begin{array}{l}\text { University Rules and } \\
\text { regulations }\end{array}$} & $\begin{array}{l}\text { Equal variances } \\
\text { assumed }\end{array}$ & .451 & .503 & -.256 & 124 & .798 \\
\hline & $\begin{array}{l}\text { Equal variances not } \\
\text { assumed }\end{array}$ & & & -.308 & 16.723 & .762 \\
\hline \multirow[t]{2}{*}{$\begin{array}{l}\text { Duration of academic } \\
\text { year }\end{array}$} & $\begin{array}{l}\text { Equal variances } \\
\text { assumed }\end{array}$ & .202 & .654 & 1.086 & 124 & .280 \\
\hline & $\begin{array}{l}\text { Equal variances not } \\
\text { assumed }\end{array}$ & & & .956 & 14.082 & .355 \\
\hline \multirow[t]{2}{*}{ Financial Audit } & $\begin{array}{l}\text { Equal variances } \\
\text { assumed }\end{array}$ & 2.212 & .139 & -.775 & 124 & .440 \\
\hline & $\begin{array}{l}\text { Equal variances not } \\
\text { assumed }\end{array}$ & & & -1.115 & 19.887 & .278 \\
\hline \multirow{2}{*}{$\begin{array}{l}\text { Preparation and } \\
\text { allocation of university } \\
\text { budget }\end{array}$} & $\begin{array}{l}\text { Equal variances } \\
\text { assumed }\end{array}$ & 2.954 & .088 & -.895 & 124 & .373 \\
\hline & $\begin{array}{l}\text { Equal variances not } \\
\text { assumed }\end{array}$ & & & -1.402 & 22.283 & .175 \\
\hline \multirow{2}{*}{$\begin{array}{l}\text { Approval of commercial } \\
\text { or money making } \\
\text { projects }\end{array}$} & $\begin{array}{l}\text { Equal variances } \\
\text { assumed }\end{array}$ & 4.569 & .035 & -.090 & 124 & .929 \\
\hline & $\begin{array}{l}\text { Equal variances not } \\
\text { assumed }\end{array}$ & & & -.138 & 21.602 & .892 \\
\hline \multirow[t]{2}{*}{$\begin{array}{l}\text { Approval of major } \\
\text { capital expenditure }\end{array}$} & $\begin{array}{l}\text { Equal variances } \\
\text { assumed }\end{array}$ & 1.418 & .236 & -.540 & 124 & .590 \\
\hline & $\begin{array}{l}\text { Equal variances not } \\
\text { assumed }\end{array}$ & & & -.717 & 18.225 & .483 \\
\hline \multirow[t]{2}{*}{ Level of tuition fees } & $\begin{array}{l}\text { Equal variances } \\
\text { assumed }\end{array}$ & 3.556 & .062 & -1.542 & 124 & .126 \\
\hline & $\begin{array}{l}\text { Equal variances not } \\
\text { assumed }\end{array}$ & & & -2.400 & 22.068 & .025 \\
\hline $\begin{array}{l}\text { Financial support to } \\
\text { students }\end{array}$ & $\begin{array}{l}\text { Equal variances } \\
\text { assumed }\end{array}$ & 3.035 & .084 & -.515 & 124 & .607 \\
\hline
\end{tabular}




\begin{tabular}{|c|c|c|c|c|c|c|}
\hline & & \multicolumn{2}{|c|}{$\begin{array}{l}\text { Levene's } \\
\text { for Equality } \\
\text { Variances }\end{array}$} & \multicolumn{3}{|c|}{ t-test for Equality of Means } \\
\hline & & $\mathrm{F}$ & Sig. & $\mathrm{t}$ & df & $\begin{array}{l}\text { Sig. (2- } \\
\text { tailed) }\end{array}$ \\
\hline & $\begin{array}{l}\text { Equal variances not } \\
\text { assumed }\end{array}$ & & & -.817 & 22.675 & .422 \\
\hline \multirow[t]{2}{*}{ Accountability } & $\begin{array}{l}\text { Equal variances } \\
\text { assumed }\end{array}$ & 3.917 & .050 & -.504 & 124 & .615 \\
\hline & $\begin{array}{l}\text { Equal variances not } \\
\text { assumed }\end{array}$ & & & -.656 & 17.886 & .520 \\
\hline
\end{tabular}

\section{References}

[1] Aghion, P., Dewatripont, M., Hoxby, C., Mas-Colell, A., \& Sapir, A. (2010). The governance and performance of universities: evidence from Europe and the US. Economic Policy, 25(61), 7-59.

[2] Al-haimi, B., Ab Hamid, M., \& Hujainah, F. (2018). FACTORS AFFECTING YEMEN HIGHER EDUCATION INSTITUTIONS PERFORMANCE: CHALLENEGES \& OBSTACLES. International Journal of Engineering \& Technology, 7, 256-260.

[3] Bladh, A. (2007). Institutional autonomy with increasing dependency on outside actors. Higher Education Policy, 20(3), 243-259.

[4] Education, M. o. H. (2007). National higher education action plan 2007-2010: Author Putrajaya, Malaysia.

[5] Estermann, T., Nokkala, T., \& Steinel, M. (2011). University autonomy in Europe II. The Scorecard. Brussels: European University Association.

[6] Fielden, J. (2008). Global trends in university governance. Education working paper series, 9, 278200-1099079877269.

[7] Henard, F., \& Mitterle, G. (2009). quality guidelines in Higher Education" IMHE: OECD.

[8] Hock-Eam, L., Taib, F. M., Abdullah, H., Adiana, N., \& Hwa, Y. S. (2016). HOW EFFICIENT ARE MALAYSIAN PUBLIC UNIVERSITIES? A COMPARATIVE ANALYSIS USING DATA ENVELOPMENT ANALYSIS. Asian Academy of Management Journal, 21(2).

[9] Kimenyi, M. S. (2011). Contribution of higher education to economic development: A survey of international evidence. Journal of African Economies, 20(suppl_3), iii14iii49.

[10] Lee, J. (2013). Creating world-class universities: Implications for developing countries. Prospects, 43(2), 233-249. 
[11] Levy, D. C. (1980). University and Government in Mexico: Autonomy in an Authoritarian System.

[12] Milton, S., \& Barakat, S. (2016). Higher education as the catalyst of recovery in conflictaffected societies. Globalisation, Societies and Education, 14(3), 403-421.

[13] Sadlak, J., \& Liu, N. C. (2007). The world-class university and ranking: Aiming beyond status: Unesco-Cepes Bucharest.

[14] Salmi, J. (2009). The challenge of establishing world-class universities: World Bank Publications.

[15] Sharma, Y. (2011). How to create a world-class university. Journal of World University New, 192, 59-63.

[16] Sirat, M. (2013). Malaysia's world-class university ambition: An assessment Institutionalization of world-class university in global competition (pp. 205-223): Springer.

[17] SUFEAN HUSSIN, S. A. A. I. (2019). ASSESSEMNT OF UNIVERSITY GOVERNANCE AND AUTONOMY IN MALAYSIA. In M. S. Chang Da Wan, Dzulkifli Razak (Ed.), HIGHER EDUCATION IN MALAYSIA: A critical Review of the Past and Present for the Future. Uinversity Sains Malayisa: Penerbit Unievrsity Sains Malaysia.

[18] Wan, C. D. (2017). The History of University Autonomy in Malaysia. Retrieved from http://www.ideas.org.my/wp-content/uploads/2017/06/The-Historyof-University-Autonomy-in-Malaysia-.pdf

[19] WUS. (1988). The Lima Declaration on Academic Freedom and Autonomy of Institutions of Higher Education. Geneva, Swezrland: World University Services Retrieved from https://www.wusgermany.de/sites/wusgermany.de/files/ userfiles/WUS-Internationales/wus-lima-englisch.pdf. 